\section{Entrapment Neuropathies}

In a communication made to the Royal Society in 1862 A. G. Waller described in detail the various " sensory, motory and vasomotory" phenomena which followed experimental " compression " of various nerves of the upper limbs. ${ }^{1}$ He made no reference to the mechanism whereby nerve conduction was impeded in these experiments, presumably because it must have appeared self-evident to him that the nerve block was due to pressure. H. Grundfest's classic demonstration that conduction in a nerve is not affected by compression had to wait a further seventy-four years. ${ }^{2}$ He found that a pressure of 1,000 atmospheres was necessary to abolish nerve conduction. It is therefore widely accepted now that the effects of compressing and stretching a mammalian nerve trunk within the ranges occurring under clinical conditions are in the main due to obliteration of vasa nervorum. ${ }^{3}$

Peripheral nerves often have fusiform enlargements. These "pseudoganglia" are generally sited where an unyielding neighbouring structure impinges closely on the nerve. ${ }^{4-8}$ These enlargements are composed of connective tissue of the nerve, and they are important as indicators of the anatomical sites where peripheral nerves are frequently subjected to mechanical embarrassment. In recent years many such sites have been recognized and have been given the name of "entrapment points." "These are usually places where a nerve is funnelled through a confined and unyielding passage. Entrapment points are best viewed as places where the nerve is particularly vulnerable to focal ischaemia.

When mechanical deformation of the nerve is such as to cause paralysis-motor or sensory-the diagnosis of nerve entrapment presents little difficulty. Such clear evidence of paralysis as a result of entrapment may be lacking, despite the distressing nature of the symptoms. The following are some

1 Waller, A., Proceedings of the Royal Society, London, 1862, 12, 89.

2 Grundfest, H., Cold Spring Harbor Symposia on Quantitative Biology, 1936, 4, 179.

3 Richards, R. L., fournal of Neurology, Neurosurgery and Psychiatry, $1951,14,76$.

- Sunderland, S., and Bradley, K. C., Anatomical Record, 1952, 113, 125.

5 Daniell, H. W., fournal of Neuropathology and Experimental Neuro$\log y, 1954,13,467$.

- Nathan, H., fournal of Neurosurgery, 1960, 17, 843.

7 Gitlin, G., Fournal of Anatomy, 1957, 91, 466.

Chang, K. S. F., Low, W. D., Chan, S. T., Chuang, A., and Poon, K. T., Anatomical Record, 1963, 145, 149.

- Kopell, H. P., and Thompson, W. A. L., Peripheral Entrapment Neuropathies, 1963. Baltimore, The William \& Wilkins Company.

10 Behrman, S., British Medical fournal, 1959, 1, 1527.

1 Norris, F. H., The E.M.G., 1963, p. 73. New York, Grune \& Stratton.

12 Lewis, T., Pickering, G. W., and Rothschild, P., Heart, 1933, $16,1$.

${ }_{13}$ Porter, E. L., and Wharton, P. S., fournal of Neurophysiology, 1949, 12, 109

14 Behrman, S., Proceedings of the Royal Society of Medicine, 1945, 38, 600.

15 Johnston, A. W., British Medical fournal, 1960, 1, 1616.

16 Purnell, D. C., Daly, D. D., and Lipscomb, P. R., Archives of Internal Medicine, 1961, 108, 751.

17 Jelliffe, S. E., Fournal of Nervous and Mental Diseases, 1934, 79, 631.

18 Brook, D. M., fournal of Bone and foint Surgery, 1952, 34B, 391.

19 Seddon, H. J., Fournal of Bone and foint Surgery, 1952, 34B, 386.

20 Richmond, D. A., Fournal of Bone and foint Surgery, 1953, 35B, 83.

21 White, W. L., and Hanna, D. C., foumal of Bone and foint Surgery, $1962,44 \mathrm{~A}, 1353$.

22 Hyslop, G. H., American fournal of Surgery, 1941, 51, 436.

${ }_{23}$ Nobel, W., fournal of Bone and foint Surgery, 1966, 48A, 1484.

24 Sidey, J. D., British Medical foumal, 1969, 3, 623.

25 Behrman, S., British Medical fournal, 1958, 1, 1454.

${ }^{26}$ Gowers, Sir W., Lancet, 1902, 1, 1002.

27 Omerod, J. A., St. Bartholomew's Hospital Reports, 1883, 19, 17.

28 Omerod, J. A., Clinical fournal, 1908, 32, 1.

29 British Medical fournal, 1959, 1, 1230. positive and negative clinical features which may be of assistance in recognizing the syndrome of non-paralytic nerve entrapment: (a) Tactile paraesthesiae and pain are provoked by immobilization of a limb, and these symptoms are relieved by activity ; $(b)$ paradoxically, liability to these symptoms is increased by prolonged activity and relieved by a period of rest $^{10} ;(c)$ paraneural infiltration with corticosteroids at the entrapment point relieves the symptoms ; $(d)$ electroneuromyography may show either undue prolongation of conduction time or prolongation of the evoked potential ${ }^{11}$; $(e)$ decompression of the nerve immediately relieves the symptoms; ( $f$ ) the blood supply in the affected region is not impoverished.

Pains and paraesthesiae are often distressing, poorly localized, and associated with pseudocramps-mainly subjective feelings of cramp. ${ }^{12}$ Nerves made hyperexcitable by ischaemia to a degree when they commence to fire spontaneously into the central nervous system explain these various abnormal symptoms. ${ }^{13}$ But the sensory symptoms cannot by themselves form the basis for a diagnosis of entrapment neuropathy without reference to the other diagnostic criteria listed.

Owing to their mechanical characteristics entrapment points are places where the blood supply to the nerve is readily compromised. Swelling of the paraneural tissue there may produce this effect and thus account for the abrupt onset of symptoms in pregnancy, acromegaly, myxoedema, and Paget's disease. ${ }^{14-17}$ Tumours of various kinds in these situations can start off a similar train of symptoms. Synovial herniation arising from joint capsules and tendon sheaths-simple ganglion-and lipomas are the main causes of trouble..$^{18-21}$ Points of nerve entrapment may also become points of nerve attachment, where injury follows excessive traction on the nerve. G. H. Hyslop has described transient peroneal nerve palsy as following inversion sprain of the ankle. ${ }^{22}$

As a result of the paraneural attachment at the entrapment point haematomas have been observed between the epi- and perineurium when the nerve was subjected to exceptional traction. ${ }^{23}$ The nerve at the entrapment point in relation to a joint which has become a seat of osteoarthritis may suffer focal ischaemia as a result of spread of the inflammatory process from the joint to the contiguous paraneural connective tissue.

J. D. Sidey ${ }^{24}$ has recently illustrated the diagnostic difficulties presented by entrapment neuropathy as it affects the common peroneal nerve. His aphorism "the history is often characteristic and the clinical signs are few " is fully justified, but the statement that entrapment neuropathy unlike other forms of "peripheral neuritis" does not cause loss of tendon jerks is open to question. From the information given it seems possible that some of his cases may have been of other syndromes causing pain in the leg at rest. ${ }^{25}$

Sir William Gowers ${ }^{26}$ once wrote : "If we have a conception for which no name exists, which we need frequently to speak of, it is not wise, I think, to shrink from an attempt to give it a name." In accord with this precept the syndrome of nonparalytic focal ischaemic neuropathy, because of its frequency, lays claim to a name. J. A. Ormerod ${ }^{27}$ gave an excellent description of the commonest variant of this syndrome, and later used the term "acroparaesthesia" to denote it. ${ }^{28}$ This name was subsequently used to describe a variety of conditions, though a decade ago it again appeared in the original Ormerod connotation in a leading article in the B.M.Y. ${ }^{29}$ But if its meaning is now somewhat confused perhaps " non-paralytic entrapment neuropathy" may supersede it. 